УДК 662.276.6

\title{
ВОПРОСЫ ПРИМЕНЕНИЯ ТЕХНОЛОГИЙ, ОСНОВАННЫХ НА ВОЛНОВЫХ ПРОЦЕССАХ ОБРАБОТКИ ПРОДУКТИВНЫХ ПЛАСТОВ, ДЛЯ ИНТЕНСИФИКАЦИИ ПРИТОКА ФЛЮИДОВ В СКВАЖИНУ
}

\author{
Дубинский Геннадий Семенович \\ к.т.н., доцент, с.н.с. \\ Чибисов Александр Вячеславович \\ к.т.н., с.н.с. \\ ФГБУН «Институт машиноведения им. А.А. Благонравова \\ Российской академии наук» (ИМАШ РАН) \\ ФГБОУ ВО «Уфимский государственный нефтяной технический \\ университет» (УГНТУ)
}

Аннотация: В статье рассмотрены вопросы интенсификации работы скважин и планирования воздействия на пласт. Приведены критерии выбора и пример выбора кандидатов-скважин для волновой обработки пласта для увеличения добычи нефти с использованием волновых и резонансных процессов.

Ключевые слова: призабойная зона пласта, волновая технология, резонанс, продуктивность, дополнительная добыча нефти

\section{ISSUES OF APPLICATION OF TECHNOLOGIES BASED ON WAVE PROCESSES OF PROCESSING PRODUCTIVE FORMATIONS TO INTENSIFY THE FLOW OF FLUIDS INTO THE WELL}

\section{Dubinsky Gennady Semenovich Chibisov Aleksandr Veacheslavovich}

\begin{abstract}
The article deals with the issues of intensification of well work and planning of impact on the reservoir. The selection criteria and an example of the selection of candidates are given-wells for wave treatment of the formation and to increase oil recovery using wave and resonance processes.

Key words: bottomhole formation zone, productivity of well, wave technology, resonance, additional oil production
\end{abstract}


Основная доля месторождений, в настоящее время находящихся в разработке, имеют тенденцию сокращения добычи нефти и газа. Практически на всех месторождениях достигаются коэффициенты извлечения нефти (КИН) в среднем не превышающие $0,35-0,4$, хотя в отдельных случаях достигаются и значительно большие величины. Эффективность работ по удержанию достигнутых уровней добычи углеводородов часто не достигает желаемых экономических показателей.

Мероприятия, направленные на замедление падения добычи нефти и газа должны быть ориентированы на разработку и внедрение энергоэффективных, ресурсосберегающих технологий воздействия на призабойную зону пласта (ПЗП) нагнетательных в добывающих скважин, а также на целые участки залежей углеводородов. В последнее время, внимание обращено на комплексные методы охвата с различной степенью охвата продуктивного пласта воздействием (от зоны вокруг скважины до объема залежи) $[1,2,3,4,5,6,7]$. Геолого-технические мероприятия (ГТМ) проводят на нефтяных и газовых месторождениях для приведения показателей работы скважин, залежей и месторождений к соответствию с их потенциалом. Наибольший эффект от управляющего воздействия на процесс разработки достигается при системном проведении ГТМ на объектах нефте- и газодобычи $[1,2,3,4,5,7,9,10,11,12]$.

Выбор скважин-кандидатов и объектов-кадидатов для того или иного воздействия является важнейшим этапом реализации ГТМ. Вопросам научнотехнологического и геологического комплексного подхода к решению такой задачи уделяется большое внимание $[1,4,5,7,8,9,10,11,12,13]$. Для достижения высокой эффективности извлечения остаточных и трудноизвлекаемых запасов нефти (ОЗ и ТРИЗ) следует планировать адресное воздействие на скважины и залежи основе метотехнологического подхода $[11,13,14]$. Для прогноза необходимости и типа обработки ПЗП в скважине, с упавшей производительностью, анализируются геолого-физические свойства пласта и состояние ПЗП, определяют причины отклонения от режима работы скважины или проектных показателей разработки участка залежи. Рекомендуется предварительно моделировать процессы в призабойной зоне и/или на участке залежи.

Важным аспектом работ по интенсификации добычи является планирование мероприятий, начиная от освоения скважины до времени ее продолжительной эксплуатации, когда решается вопрос о переводе из эксплуатационного фонда $[1,2,4,5,9,15,16]$. Размеры нефтенасыщенной 
части пласта-резервуара в дренажной зоне эксплуатационной скважины зависит от его свойств: эффективной толщины, коэффициентов пористости и нефтенасыщенности. Дебиты скважин зависят от объема нефти внутри контура питания, проницаемости продуктивного пласта и депрессии на пласт. Ощутимо вовлечь в движение нефть и газ в недренируемых зонах пласта можно дополнительным введением энергии в этот пласт, с применением волновых процессов и связанных с ними резонансных явлений $[3,15,16]$. Применение методов волнового воздействия на нефтяные пласты для увеличения подвижности нефти и деструктурирования матрицы коллектора, позволит повысить полноту вытеснения нефти [15, 16, 17]. При волновом воздействии интенсифицируются процессы фильтрации, вовлекаются в движение флюиды защемленные в мелких порах, сдвигаются твердые частицы и капли, блокирующие фильтрацию $[3,15,16]$.

Под руководством академика Ганиева Р.Ф. разработана теория и основы практического использования резонансной макро- и микромеханики нефтяного пласта [3, 15, 16]. Предусмотрено применение разработанной технологии и устройств совместно с другими известными традиционными методами увеличения нефтеотдачи (МУН) - химических, тепловых, гидроразрыва пластов, горизонтальных скважин и др. Совместное применение традиционных методов с волновыми и резонансными позволяет нарастить технологическую эффективность обработки продуктивных пластов $[3,15,16]$. Ученые - практики в своих работах [17] отмечают перспективность волновых технологий, которые уже были опробованы и продолжают развиваться.

Для вызова фильтрационного течения со скоростью, сравнимой со скоростью потока при действии перепада давления, колебаниями давления резонансной частоты с амплитудой всего $10^{5}$ Па (1 физическая атмосфера), в стационарном режиме необходимо создать градиент давления порядка $20 \cdot 10^{5}$ Па/м, а на практике при закачке воды в пласт для поддержании давления удается создавать градиенты до $0,3 \div 0,4 \cdot 10^{5}$ Па/м $[15,16]$. Т.е. волновое и резонансное воздействие может возбуждать пластовую систему и инициировать такие фильтрационные течения, которые при традиционном вызове движения флюидов могут достигаться только созданием очень большого градиента давления в пласте, который практически в практике разработки не достижим.

После обобщения геолого-физических характеристик пластовых систем и физико-химических свойств насыщающих их флюидов месторождений ПАО «Татнефть» в 2020 году был выполнен подбор типичных объектов для 
реализации технологий волнового воздействия на продуктивный пласт (12 скважин).

Из расчета достижения определенных эффектов при волновом резонансном воздействии через забой скважины на нефтенасыщенный пласт, конструктивных особенностей волновых генераторов, общих критериев применимости волнового воздействия и типичных условий месторождений Татарстана были уточнены критерии подбора объектов-кандидатов для ВВ. Для ОПЗП в скважинах:

— эффективная пористость коллектора не менее 8-10\%;

— эффективная проницаемость (определенная по КВД) не менее 0,010 $\mathrm{MKM}^{2}$;

- наличие слабодренируемого (или недренируемого) пропластка, отличающегося по проницаемости от хорошо дренируемого (в интервале перфорации);

- подтвержденная информация о кольматации (загрязнении) ПЗП, $\mathrm{S} \geq+1$ (СКИН-эффект).

- О3 в зоне дренирования скважины более 5000 тонн;

- дебит добывающей скважины по жидкости более 4 м³/сут, обводненность продукции не более 80 \%; приемистость нагнетательной - не ограничена (рекомендуется для точного определения эффективности не менее $30 \mathrm{M}^{3} /$ сут).

- пластовое давление не ниже гидростатического, рассчитанного по нефти, или по крайней мере не менее, чем на 80\% гидростатического;

- аномально низкий дебит (приемистость) добывающей (нагнетательной) скважины при схожих параметрах продуктивного пласта в сравнении с соседними скважинами (окружающими);

— падение дебита (приемистости) скважины на 50\% и более в течение года;

- эксплуатационная колонна скважины должна быть исправной и не иметь резких сужений внутреннего размера (уменьшение диаметра не более 6 $\mathrm{MM)}$;

- глубина зумпфа скважины более 2 м.

Таким образом, с целью выбора скважин-кандидатов был проанализирован геолого-промысловый материал в полном объеме. Изучена динамика показателей эксплуатации скважин: дебиты жидкости и нефти, обводненность, продуктивность, пластовые и забойные давления. Уточнены 
конструктивные особенности оборудования скважин. Проанализированы заключения геофизических и гидродинамических исследований. Выполнен анализ динамики коэффициента продуктивности скважин и СКИН эффекта.

В общей сложности, в соответствии с вышеперечисленными критериями подбора скважин-кандидатов, для проведения стимуляции скважин методом волновой обработки ПЗП отобрано 9 добывающих и 3 нагнетательных скважины. Волновые обработки скважин были выполнены комплексно с реагентным и кислотным воздействием. В целом получен положительный эффект. После тщательного исследования результатов будет уточнена технология и подобраны новые объекты воздействия.

\section{Список литературы}

1. Андреев В.Е. и др. Обоснование комплексирования физикохимических и гидродинамических методов увеличения нефтеотдачи на Ватьёганском месторождении / Андреев В.Е., Котенев Ю.А., Чижов А.П., Чибисов А.В., Федоров К.М., Галимов Ш.С. // Проблемы сбора, подготовки и транспорта нефти и нефтепродуктов. 2010. № 3 . С. 5-14.

2. Андреев В.Е. и др. Планирование и обоснование технологии интенсификации притока в залежах высоковязких нефтей / Андреев В.Е., Дубинский Г.С., Котенев Ю.А., Пташко О.А. Мияссаров А.Ш. Хузин Р.Р. Хузин Н.И. // Нефтегазовые технологии и новые материалы (проблемы и решения). Вып. 1(16). - Уфа: ООО «Монография», 2012. - с. 91-93.

3. Ганиев Р.Ф., Украинский Л.Е., Андреев В.Е. Котенев Ю.А. Проблемы и перспективы волновой технологии многофазных систем в нефтяной и газовой промышленности. - СПб.: ООО «Недра», 2008. - 214 с.

4. Дубинский Г.С. О необходимости интенсификации притока при вскрытии пласта и освоении скважины // Инновации и наукоемкие технологии в образовании и экономике: материалы VIII Междунар. науч.-практ. конф., (г. Уфа, 30-31 мая 2019 г.). - Уфа, 2019. - С. 128-134.

5. Дубинский Г.С., Андреев В.Е. Прогноз применения технологий ГРП и волнового воздействия для освоения трудноизвлекаемых запасов нефти в условиях месторождений Республики Башкортостан // Сборник научных трудов Института стратегических исследований Республики Башкортостан: сборник статей / ред. А.В. Янгиров, С.И. Насырова. - Уфа: АЭТЕРНА, 2019. C. 88-96. 
6. Дубинский Г.С. Волновое воздействие как способ увеличения извлекаемых запасов нефти // Современная наука и ее ресурсное обеспечение: инновационная парадигма: сборник статей IV Международной научнопрактической конференции (22 мая 2020 г.) - Петрозаводск: МЦНП «Новая наука», 2020. - С. 113-116.

7. Чижов А.П. и др. Комплексное воздействие на остаточные и трудноизвлекаемые запасы нефти / Чижов А.П., Чибисов А.В., Щербинин В.Г., Галимов Ш.С. / В сборнике: Уфа, 2014. С. 175-182.

8. Дубинский Г.С. и др. Алгоритм геолого-технологического обоснования применения адресных технологий освоения трудноизвлекаемых запасов нефти / Дубинский Г.С., Андреев В.Е., Мияссаров А.Ш., Хузин Р.Р., Хузин Н.И. // В сборнике: Нефтегазовые технологии и новые материалы. Проблемы и решения Сборник научных трудов. Уфа, 2013. С. 253-262.

9. Дубинский Г.С. Геологические особенности залежей с трудноизвлекаемыми запасами углеводородов и их влияние на выбор технологии освоения запасов // Геология. Известия Отделения наук о Земле и природных ресурсов Академия наук Республики Башкортостан. - 2015. № 21. - С. 70-75.

10. Дубинский Г.С. О планировании технологий стимуляции скважин и ограничения водопритока // Нефтегазовые технологии и новые материалы. Проблемы и решения. Сборник научных трудов. Вып. 4(9). - Уфа: ООО «Монография», 2015.- с.138-146.

11. Султанов Ш.Х. Метотехнология системного анализа разработки нефтяных месторождений с различными категориями трудноизвлекаемых запасов. - Уфа: ООО «Монография», 2009.- 204 с.

12. Чибисов А.В. и др. Перспективы освоения трудноизвлекаемых запасов нефти карбонатных пластов с применением нестационарного заводнения / Чибисов А.В., Чижов А.П., Архипова Н.Н., Кагарманова Е.В. // Сборник материалов Международной научно-практической конференции «Инновационные технологии в нефтегазовом комплексе» Уфа, 2014. С. 166171.

13. Андреев В.Е., Дубинский Г.С. Метотехнологический подход как научная методология решения проблем в нефтегазодобыче // Нефтегазовые технологии и новые материалы (проблемы и решения). Сборник научных трудов. Вып. 1(16). - Уфа: ООО «Монография», 2012.- с. 36-44.

14. Дубинский Г.С., Давлетов Р.Ш. О необходимости планирования дополнительных мероприятий при освоении скважин из бурения // Методы 
увеличения нефтеотдачи трудноизвлекемых запасов. Проблемы и решения. Выпуск 4. - Уфа: Изд. «Монография», 2003. С.160-165.

15. Ганиев Р.Ф., Украинский Л.Е., Ганиев О.Р. Приложение эффектов нелинейной волновой механики в процессах нефтегазодобычи //VI Конгресс нефтепромышленников России. Секция В «Проблемы освоения трудноизвлекаемых запасов углеводородов» (Уфа, 25 мая 2005): Научные труды / Уфа: Монография, 2005. С. 10-15.

16. Ганиев О.Р., Ганиев Р.Ф., Украинский Л.Е. Резонансная макро- и микромеханика нефтяного пласта. Интенсификация добычи нефти и повышение нефтеотдачи. Наука и практика. - М. - Ижевск: Институт компьютерных исследований. - 2014. - 256 с.

17. Муслимов Р.X. Нефтеотдача: прошлое, настоящее и будущее. - Казань: Изд. АН Республики Татарстан, 2012. - 663 с.

(C) Г.С. Дубинский, А.В. Чибисов, 2021 